\title{
Pengoptimalan dosis dan waktu papar aplikasi sulfuril fluorida pada ketebalan kayu berbeda untuk pengendalian rayap kayu kering
}

\author{
Optimization of dose and exposure time for application of \\ sulfuryl fluoride on different depths of wood for the control of \\ Indo-Malaysian drywood termite
}

\author{
Ahmad Mansuri Alfian ${ }^{1}$, Idham Sakti Harahap ${ }^{2}$, Swastiko Priyambodo ${ }^{2}$ \\ ${ }^{1}$ Stasiun Karantina Pertanian Kelas II Mamuju \\ Jalan H. Abd Malik Pattana Endeng, Kabupaten Mamuju, Sulawesi Barat 91512 \\ ${ }^{2}$ Departemen Proteksi Tanaman, Fakultas Pertanian, Institut Pertanian Bogor \\ Jalan Kamper, Kampus IPB Dramaga, Bogor 16680
}

(diterima Desember 2014, disetujui November 2015)

\begin{abstract}
ABSTRAK
Rayap merupakan salah satu hama yang dapat menimbulkan kerusakan berat dan kerugian besar pada produk-produk kayu. Sulfuril fluorida merupakan salah satu fumigan yang dapat digunakan untuk pengendalian rayap. Tujuan penelitian ini adalah menentukan hubungan dosis dan lama waktu pemaparan fumigan sulfuril fluorida terhadap mortalitas rayap kayu kering Cryptotermes cynocephalus Kemner dan mengevaluasi kemampuan fumigan sulfuril fluorida menjangkau rayap pada ketebalan kayu berbeda. Uji aplikasi dilakukan pada kayu karet pada tiga ketebalan, yaitu $10 \mathrm{~cm}$, $5 \mathrm{~cm}$, dan 2,5 cm. Pada ketebalan kayu $10 \mathrm{~cm}$ dilakukan dengan 5 variasi dosis $\left(10-30 \mathrm{~g} / \mathrm{m}^{3}\right)$ dan 4 lama waktu pemaparan (6-24 jam). Sedangkan untuk uji aplikasi pada ketebalan kayu 5 dan $2,5 \mathrm{~cm}$ dilakukan dengan 4 variasi dosis $\left(2-15 \mathrm{~g} / \mathrm{m}^{3}\right)$ dan 4 lama waktu pemaparan (1-9 jam). Penelitian ini menggunakan rancangan acak lengkap faktorial (RALF). Hasil penelitian menunjukkan aplikasi sulfuril fluorida pada ketebalan kayu $10 \mathrm{~cm}$ lebih efektif untuk mengendalikan rayap kayu kering pada dosis $30 \mathrm{~g} / \mathrm{m}^{3}$ dengan lama waktu pemaparan $18 \mathrm{jam}$ atau dosis $15 \mathrm{~g} / \mathrm{m}^{3}$ dengan waktu pemaparan 24 jam. Aplikasi sulfuril fluorida pada ketebalan kayu $5 \mathrm{~cm}$ efektif dilakukan menggunakan dosis $10 \mathrm{~g} / \mathrm{m}^{3}$ dengan waktu pemaparan $9 \mathrm{jam}$. Sedangkan pada ketebalan kayu balok 2,5 $\mathrm{cm}$ efektif menggunakan dosis $15 \mathrm{~g} / \mathrm{m}^{3}$ dengan waktu pemaparan $6 \mathrm{jam}$. Hubungan dosis dan waktu pemaparan sulfuril fluorida pada ketebalan kayu $10 \mathrm{~cm}$ menunjukkan variabel dosis fumigan merupakan variabel dominan daripada variabel waktu pemaparan terhadap keefektifan dosis (dosage), sedangkan pada ketebalan kayu 5 dan 2,5 cm menunjukkan hal yang sebaliknya.
\end{abstract}

Kata kunci: Cryptotermes cynocephalus, fumigasi, hubungan dosis dan waktu

\begin{abstract}
One of the most damaging pests attacking wood products are termites. As a control measure, the fumigant sulfuryl fluoride is commonly used. A study was conducted to determine the doseexposure and length of time needed for sulfuryl fluoride in killing dry wood termite, Cryptotermes cynocephalus Kemner, and to evaluate the ability of the fumigant to penetrate rubber wood block. Application and penetration of the fumigant was tested on a $-10 \mathrm{~cm}$ depth wood block, using five different doses (10-30 g/m $\left.\mathrm{m}^{3}\right)$ and four different exposure time (6-24 hours). Applications of the

*Penulis korespondensi: Ahmad Mansuri Alfian. Stasiun Karantina Pertanian Kelas II Mamuju, Jalan H. Abd Malik Pattana Endeng, Kabupaten Mamuju, Sulawesi Barat 91512

Tel: 0426 2325261,2325109,Email: yoyo_ewako@yahoo.com.
\end{abstract}


fumigant were tested on an -5 and $2.5 \mathrm{~cm}$ depth wood block. Doses were applied using four different doses $\left(2-15 \mathrm{~g} / \mathrm{m}^{3}\right)$ and four different exposure time (1-9 hours). The study was conducted using randomized complete design with two factors. Results showed that the application of sulfuryl fluoride can effectively penetrate a depthness of $10 \mathrm{~cm}$ wood block. The dose that was effective was $30 \mathrm{~g} / \mathrm{m}^{3}$ with 18 hours exposure time or a dose of $15 \mathrm{~g} / \mathrm{m}^{3}$ with 24 hours exposure time. Application on a-5 cm depth wood block effectively requires a dose of $10 \mathrm{~g} / \mathrm{m}^{3}$ with 9 hours exposure, while a depth penetration of $2.5 \mathrm{~cm}$ needs a dose of $15 \mathrm{~g} / \mathrm{m}^{3}$ with 6 hours exposure time. Dose-time relationship for application of sulfuryl fluoride on the penetration of a $10 \mathrm{~cm}$ wood block, showed that dosage is a much more important variable compared to time of exposure, while the penetration of the 5 and $2.5 \mathrm{~cm}$ wood block showed otherwise, e.g exposure time is more important than dosage of fumigant.

Key words: Cryptotermes cynocephalus, fumigation, dose-time relationship

\section{PENDAHULUAN}

Indonesia merupakan salah satu negara yang mempunyai wilayah hutan yang cukup luas dan merupakan negara terpenting sebagai penghasil berbagai jenis kayu (Sumargo et al. 2011). Berbagai jenis kayu hasil produksi hutan dan produk kayu olahan diekspor ke negara lain dan menjadi penyumbang devisa negara dari sektor non migas. Adanya serangan organisme perusak kayu dapat menyebabkan menurunnya nilai ekspor berbagai macam jenis kayu dan produk kayu tersebut.

Salah satu organisme perusak kayu dan produk kayu adalah rayap. Rayap merupakan salah satu hama yang dapat menimbulkan kerusakan berat dan kerugian besar pada produk-produk kayu. Rayap juga merupakan faktor perusak bangunan yang paling mengganggu. Hal ini bukan saja karena kasus serangannya yang sangat banyak dan terjadi hampir di seluruh daerah di Indonesia, tetapi juga karena kerugian ekonomis yang ditimbulkannya sangat besar (Siregar \& Batubara 2007). Di Indonesia telah ditemukan tidak kurang dari 200 jenis rayap, lima jenis di antaranya tercatat sebagai perusak kayu dan bangunan gedung yang paling penting, yaitu Coptotermes curvignathus Holmgren, Schedorhinotermes javanicus Kemner, Macrotermes gilvus Hagen, Microtermes inspiratus Kemner, dan Cryptotermes cynocephalus Light (Pearce 1997).

Fumigasi sebagai salah satu perlakuan karantina tumbuhan bertujuan untuk membebaskan produk kayu dari berbagai jenis rayap. Hal ini sesuai dengan tujuan penyelenggaraan kegiatan karantina tumbuhan, yaitu mencegah masuk dan tersebarnya OPT sehingga fumigasi sebagai perlakuan karantina harus dapat membunuh serangga hama secara sempurna (zero tolerant). Metil bromida telah digunakan selama 40 tahun terakhir sebagai bahan utama fumigasi dalam pengendalian serangga-serangga hama pada bahan simpanan, kemasan kayu, dan pengolahan pangan. Saat ini metil bromida telah dimasukkan ke dalam daftar bahan yang harus dihapus (phasing out) karena termasuk salah satu bahan kimia yang dapat menyebabkan menipisnya lapisan ozon (UNEP 2014). Di bawah ketentuan Protokol Montreal pada tahun 1998 beberapa negara telah mengurangi bahkan menghapus penggunaan metil bromida sebagai bahan fumigasi. Oleh karena itu, diperlukan berbagai alternatif untuk pengendalian rayap mengingat besarnya kerugian ekonomis yang dapat diakibatkan serangan rayap.

Salah satu fumigan alternatif pengganti metil bromida adalah sulfuril fluorida. Sulfuril fluorida pertama kali diregistrasi oleh U.S. Environmental Protection Agency pada bulan Desember 1959. Sulfuril fluorida merupakan insektisida yang berspektrum luas dan rodentisida. Sulfuril fluorida digunakan untuk pengendalian hama rumah tangga dan hama bangunan (Leis 2007).

Hubungan antara dosis dan waktu paparan fumigan sulfuril fluorida terhadap rayap kayu kering belum banyak diketahui sehingga perlu dilakukan penelitian tentang hal tersebut. Dosis dan waktu yang efektif juga harus divalidasi untuk fumigan sulfuril fluorida terhadap rayap kayu kering untuk menjamin waktu paparan yang singkat dan dosis tinggi yang digunakan dalam pelaksanaan fumigasi. Selain itu, daya tembus sulfuril fluorida pada produk kayu sangat penting diketahui sebagai bahan kajian pengganti penggunaan fumigan metil bromida terhadap kemasan kayu yang selama ini digunakan berdasarkan International Standard for Phytosanitary Measures (ISPM) No. 15.

Tujuan penelitian ini adalah menentukan hubungan dosis dan waktu pemaparan fumigasi sulfuril fluorida terhadap mortalitas rayap kayu 
kering C. cynocephalus dan mengevaluasi kemampuan fumigan sulfuril fluorida menjangkau rayap pada ketebalan balok kayu karet.

\section{BAHAN DAN METODE}

Penelitian dilaksanakan di Laboratorium Entomologi dan Gedung Workshop Fumigasi Balai Uji Terap Teknik dan Metode Karantina Pertanian, Bekasi. Penelitian dilakukan mulai bulan Juni 2014 hingga Oktober 2014.

\section{Penyiapan serangga uji}

Serangga rayap kayu kering C. cynocephalus (Isoptera: Kalotermitidae) dikumpulkan dari koloni lapangan kemudian diaklimatisasikan selama 3 hari dalam kontainer plastik berukuran $562 \mathrm{~mm} \times 394 \mathrm{~mm} \times 345 \mathrm{~mm}$ (volume 50 liter) yang di dalamnya diletakkan potongan-potongan kecil kayu karet sebagai makanan dan disimpan di laboratorium pada suhu ruang yang diletakkan di bawah meja pemeriksaan yang berkondisi gelap. Serangga rayap kayu kering yang digunakan sebagai serangga uji adalah nimfa instar terakhir yang dikenal sebagai pseudoworker (Gambar 1). Perilaku pseudoworker tidak berbeda dengan kasta pekerja pada rayap tingkat tinggi (Tho 1992).

\section{Persiapan bahan umpan (balok uji)}

Balok uji berupa balok kayu karet dengan 3 taraf ketebalan, yaitu ukuran $50 \mathrm{~cm} \times 20 \mathrm{~cm} \times 20 \mathrm{~cm}$ (ketebalan $10 \mathrm{~cm}$ ), $50 \mathrm{~cm} \times 10 \mathrm{~cm} \times 10 \mathrm{~cm}$ (ketebalan $5 \mathrm{~cm}$ ) dan $50 \mathrm{~cm} \times 5 \mathrm{~cm} \times 5 \mathrm{~cm}$ (ketebalan $2,5 \mathrm{~cm}$ ). Balok uji dipotong menjadi 2 bagian sama panjang dan pada kedua potongan kayu dibor dengan kedalaman $10 \mathrm{~cm}$ dan diameter lubang bor $0,5 \mathrm{~cm}$ (Gambar 2).

Penentuan dosis dan waktu papar untuk menjangkau rayap pada ketebalan balok kayu yang berbeda

Pengujian diawali dengan uji pendahuluan yang dilakukan untuk menentukan kisaran waktu pemaparan minimal yang diperlukan dalam pelaksanaan perlakuan fumigasi yang dikombinasikan dengan kisaran dosis. Pengujian dilakukan dengan melakukan perlakuan fumigasi sulfuril fluorida terhadap balok uji.

Sebanyak 50 individu rayap kasta pekerja dimasukkan ke dalam lubang uji pada balok kayu dengan 3 taraf ketebalan dan balok kayu disatukan lagi dengan menggunakan perekat plastik. Perlakuan fumigasi dilakukan menggunakan ruang fumigasi berupa fumigation chamber dengan ukuran $2 \mathrm{~m}^{3}$. Kayu yang telah diinfestasi serangga diletakkan di dalam fumigation chamber yang telah

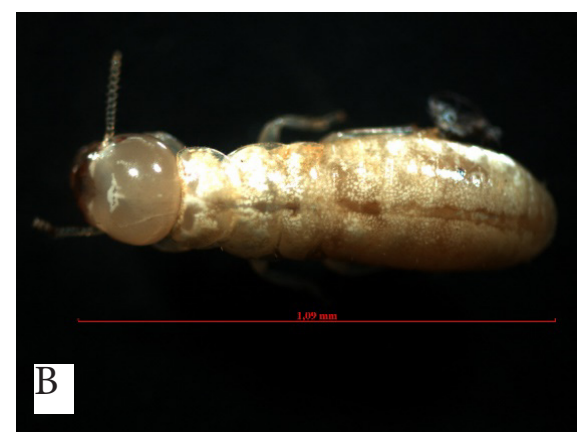

Gambar 1. Penyiapan serangga uji. A: kontainer plastik; B: pseudoworker Cryptotermes cynocephalus (perbesaran 20x).

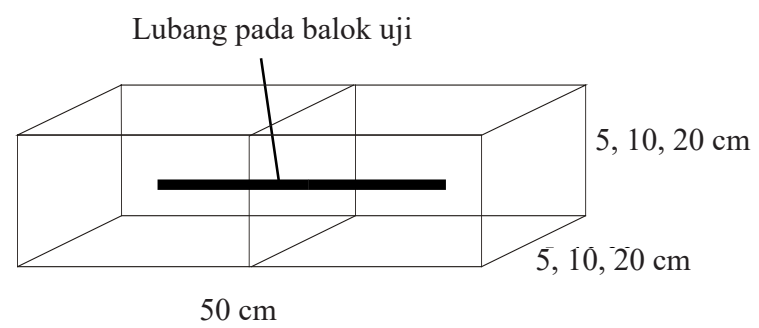

Gambar 2. Balok uji dengan ukuran kayu yang berbeda-beda $(50 \mathrm{~cm} \times 5 \mathrm{~cm}$ x $5 \mathrm{~cm}, 50 \mathrm{~cm} \times 10 \mathrm{~cm} \times 10 \mathrm{~cm}$, dan $50 \mathrm{~cm}$ x $20 \mathrm{~cm}$ x $20 \mathrm{~cm}$ ). 
ditutup dengan pelastik dan dipastikan kedap udara (Gambar 3). Pelepasan gas pada setiap fumigation chamber dilakukan dengan cara memasukan fumigan dengan dosis dan waktu papar yang ditentukan berdasarkan uji pendahuluan ke ruang fumigasi. Untuk uji ketebalan balok kayu sebesar $10 \mathrm{~cm}$, fumigasi dilakukan dengan menggunakan 6 taraf dosis, yaitu $0,10,15,20,25$, dan $30 \mathrm{~g} / \mathrm{m}^{3}$ dengan waktu pemaparan $6,12,18$, dan 24 jam, sedangkan untuk ketebalan balok kayu sebesar 5 dan $2,5 \mathrm{~cm}$ fumigasi dilakukan dengan menggunakan 5 taraf dosis, yaitu $0,2,5,10$, dan $15 \mathrm{~g} / \mathrm{m}^{3}$ dengan waktu pemaparan 1, 3, 6, dan 9 jam. Masing-masing perlakuan dilakukan dengan 4 ulangan. Model rancangan yang digunakan pada penelitian ini adalah rancangan acak lengkap faktorial (RALF). Untuk pengujian pada ketebalan kayu $10 \mathrm{~cm}$, ada 2 faktor, yaitu faktor A (dosis) dan faktor B (lama pemaparan), sedangkan untuk pengujian pada ketebalan kayu $5 \mathrm{~cm}$ dan $2,5 \mathrm{~cm}$ ada 3 faktor, yaitu faktor A (ketebalan kayu $5 \mathrm{~cm}$ menggunakan balok uji dengan ukuran $50 \mathrm{~cm} \times$ $10 \mathrm{~cm} \times 10 \mathrm{~cm}$ dan ketebalan kayu $2,5 \mathrm{~cm}$ menggunakan balok uji dengan ukuran $50 \mathrm{~cm} \times 5 \mathrm{~cm}$ $\times 5 \mathrm{~cm}$ ), faktor B (dosis), dan faktor C (lama pemaparan).

Setelah dilakukan pelepasan gas, dilakukan penutupan lubang bekas gas fumigan dimasukan. Penentuan konsentrasi gas dengan lama pemaparan selama proses fumigasi dilakukan dengan alat pengukur konsentrasi yang dihubungkan dengan selang kapiler dengan posisi ujung selang berada di tengah-tengah di dalam fumigation chamber yang telah disiapkan sebelum fumigation chamber ditutup sempurna.

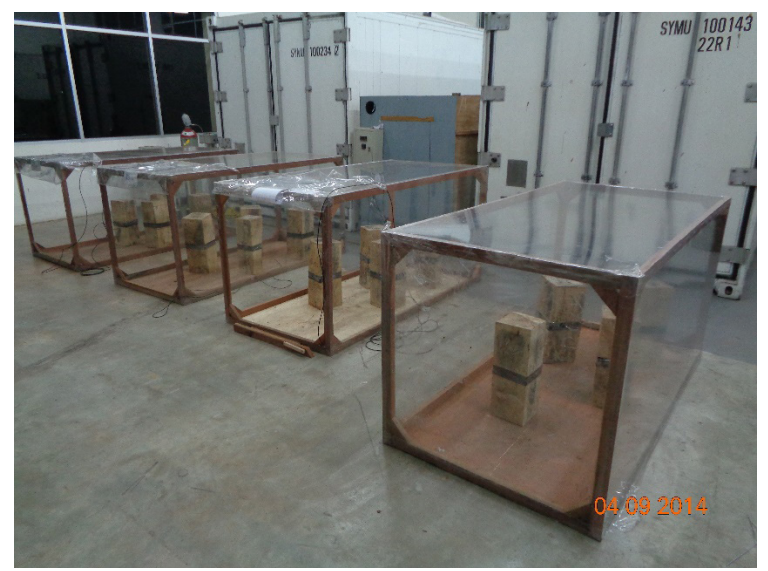

Gambar 3. Fumigation chamber dengan volume \pm $2 \mathrm{~m}^{3}$.

\section{Analisis data}

Data dianalisis menggunakan Microsoft Excel 2007, Minitab versi 14 dan SAS 9.1. Data mortalitas rayap dilakukan transformasi data dengan menggunakan arc sin. Perlakuan yang dinyatakan berpengaruh terhadap respons dalam analisis ragam, diuji lanjut dengan menggunakan uji beda nyata jujur. Letal dosis untuk tingkat mortalitas 50\%, 90\%, dan 95\% diperkirakan untuk masing-masing waktu pemaparan menggunakan analisis probit. Hubungan antara dosis dan waktu pemaparan ditentukan dengan analisis regresi dengan skala logaritmik untuk mengalkulasi indeks toksisitas $(n)$, seperti yang dijelaskan oleh Winks (1984).

\section{HASIL}

\section{Mortalitas rayap terhadap fumigasi sulfuril flourida pada ketebalan kayu yang berbeda}

Secara umum, mortalitas serangga uji akibat aplikasi sulfuril fluorida meningkat dengan makin bertambahnya dosis dan peningkatan waktu pemaparan. Pada waktu pemaparan 6 jam dan 12 jam, pengujian pada ketebalan $10 \mathrm{~cm}$ dengan dosis tertinggi $\left(30 \mathrm{~g} / \mathrm{m}^{3}\right)$ tidak mengakibatkan mortalitas rayap $C$. cynocephalus mencapai $100 \%$, masing-masing adalah $82,5 \%$ dan $98,5 \%$. Hal yang sama pada waktu pemaparan 24 jam, dengan dosis terendah $10 \mathrm{~g} / \mathrm{m}^{3}$ tidak menunjukkan mortalitas serangga uji sebesar 100\% (Tabel 1). Seperti pada pengujian ketebalan $10 \mathrm{~cm}$, pengujian pada ketebalan $5 \mathrm{~cm}$ dan $2,5 \mathrm{~cm}$ menunjukkan mortalitas serangga uji semakin meningkat dengan semakin besarnya dosis dan peningkatan waktu pemaparan (Tabel 1). Aplikasi dengan waktu pemaparan 1 jam pada ketebalan 5 dan $2,5 \mathrm{~cm}$ dengan dosis tertinggi, secara berurutan menunjukkan mortalitas masingmasing 9\% dan 17\%. Pada waktu pemaparan 3 jam, pengujian pada ketebalan $5 \mathrm{~cm}$ dengan dosis $15 \mathrm{~g} / \mathrm{m}^{3}$ mengakibatkan mortalitas $59,5 \%$, sedangkan pada ketebalan $2,5 \mathrm{~cm}$ mortalitas sudah mencapai 96\%. Pada ketebalan 5 dan $2,5 \mathrm{~cm}$ mortalitas serangga uji dicapai $100 \%$ dengan dosis $10 \mathrm{~g} / \mathrm{m}^{3}$ pada waktu pemaparan masing-masing 9 dan 6 jam. Pada ketebalan $10 \mathrm{~cm}$, mortalitas rayap C. cynocephalus dicapai $100 \%$ pada waktu 
Tabel 1. Mortalitas kasta pekerja Cryptotermes cynocephalus yang diberi perlakuan fumigan sulfuril fluorida pada ketebalan kayu yang berbeda

\begin{tabular}{|c|c|c|c|c|}
\hline \multirow{2}{*}{ Dosis $\left(\mathrm{g} / \mathrm{m}^{3}\right)$} & \multicolumn{4}{|c|}{ Mortalitas $\pm \mathrm{SD}(\%)$ dengan lama waktu pemaparan pada ketebalan kayu $10 \mathrm{~cm}$} \\
\hline & 6 jam & $12 \mathrm{jam}$ & $18 \mathrm{jam}$ & 24 jam \\
\hline 0 & $0,0 \pm 0,0 \mathrm{a}$ & $0,5 \pm 1,0 \mathrm{a}$ & $0,0 \pm 0,0 \mathrm{a}$ & $11,5 \pm 12,4 a b c$ \\
\hline 10 & $4,5 \pm 1,9 \mathrm{ab}$ & $11,0 \pm 2,6 a b c$ & $39,5 \pm 14,0$ cde & $95,5 \pm 9,0 \mathrm{gh}$ \\
\hline 15 & $12,0 \pm 1,6 a b c$ & $20,5 \pm 4,4 \mathrm{bcd}$ & $63,5 \pm 7,7$ ef & $100,0 \pm 0,0 \mathrm{~h}$ \\
\hline 20 & $19,5 \pm 4,4 \mathrm{bcd}$ & $46,5 \pm 6,6 \mathrm{de}$ & $94,5 \pm 7,2 \mathrm{gh}$ & $100,0 \pm 0,0 \mathrm{~h}$ \\
\hline 25 & $67,0 \pm 42,1$ ef & $85,0 \pm 7,7 \mathrm{fg}$ & $98,5 \pm 1,9 \mathrm{gh}$ & $100,0 \pm 0,0 \mathrm{~h}$ \\
\hline \multirow[t]{3}{*}{30} & $82,5 \pm 10,2 \mathrm{fg}$ & $98,5 \pm 1,9 \mathrm{gh}$ & $100,0 \pm 0,0 \mathrm{~h}$ & $100,0 \pm 0,0 \mathrm{~h}$ \\
\hline & \multicolumn{4}{|c|}{ Mortalitas \pm SD (\%) dengan lama waktu pemaparan pada ketebalan kayu $5 \mathrm{~cm}$} \\
\hline & 1 jam & $3 \mathrm{jam}$ & $6 \mathrm{jam}$ & $9 \mathrm{jam}$ \\
\hline 0 & $0,0 \pm 0,0 \mathrm{a}$ & $0,0 \pm 0,0 \mathrm{a}$ & $0,0 \pm 0,0 \mathrm{a}$ & $0,0 \pm 0,0 \mathrm{a}$ \\
\hline 2 & $0,5 \pm 1,0 \mathrm{a}$ & $3,0 \pm 2,6 \mathrm{abc}$ & $10,5 \pm 5,7$ bcde & $73,5 \pm 13,7 \mathrm{hi}$ \\
\hline 5 & $3,0 \pm 2,6 \mathrm{abc}$ & $11,0 \pm 5,0 \mathrm{cde}$ & $28,5 \pm 11,8$ ef & $89,5 \pm 2,5 \mathrm{ijk}$ \\
\hline 10 & $5,0 \pm 3,5$ abcd & $28,0 \pm 11,0$ ef & $72,5 \pm 20,9$ hi & $100,0 \pm 0,01$ \\
\hline \multirow[t]{3}{*}{15} & $9,0 \pm 2,6$ bcde & $59,5 \pm 16,5 \mathrm{gh}$ & $99,0 \pm 2,01$ & $100,0 \pm 0,01$ \\
\hline & \multicolumn{4}{|c|}{ Mortalitas \pm SD (\%) dengan lama waktu pemaparan pada ketebalan kayu $2,5 \mathrm{~cm}$} \\
\hline & $1 \mathrm{jam}$ & $3 \mathrm{jam}$ & 6 jam & 9 jam \\
\hline 0 & $0,0 \pm 0,0 \mathrm{a}$ & $0,0 \pm 0,0 \mathrm{a}$ & $0,5 \pm 1,0 \mathrm{a}$ & $0,5 \pm 1,0 \mathrm{a}$ \\
\hline 2 & $1,0 \pm 1,2 \mathrm{ab}$ & $6,5 \pm 3,8 \mathrm{abcd}$ & $16,0 \pm 5,2 \mathrm{de}$ & $84,5 \pm 5,0 \mathrm{ijk}$ \\
\hline 5 & $9,5 \pm 4,1$ bcde & $27,0 \pm 6,8$ ef & $46,0 \pm 14,9 \mathrm{fg}$ & $93,5 \pm 1,9 \mathrm{jkl}$ \\
\hline 10 & $13,0 \pm 5,3 \mathrm{cde}$ & $82,5 \pm 7,2 \mathrm{ij}$ & $99,0 \pm 2,01$ & $100,0 \pm 0,01$ \\
\hline 15 & $17,0 \pm 8,9 \mathrm{de}$ & $96,0 \pm 3,7 \mathrm{kl}$ & $100,0 \pm 0,01$ & $100,0 \pm 0,01$ \\
\hline
\end{tabular}

Rata-rata persentase mortalitas yang diikuti oleh huruf yang sama menunjukan tidak berbeda nyata berdasarkan uji tukey taraf $5 \%$.

pemaparan 18 jam dengan dosis aplikasi yang tertinggi $\left(30 \mathrm{~g} / \mathrm{m}^{3}\right)$.

Pada kayu ketebalan $10 \mathrm{~cm}$ dengan waktu pemaparan 6 jam, mortalitas rayap $C$. cynocephalus telah melebihi $50 \%$ sehingga selanjutnya dilakukan analisis probit untuk menentukan nilai $\mathrm{LD}_{50}$ dan $\mathrm{LD}_{95}$. Hasil analisis probit menunjukkan bahwa nilai $\mathrm{LD}_{50}$ dan $\mathrm{LD}_{95}$ pada ketebalan $10 \mathrm{~cm}$ semakin kecil dengan meningkatnya waktu pemaparan (Tabel 2). Hal ini sesuai dengan terjadinya peningkatan mortalitas mulai dari waktu pemaparan 6 dan 12 jam dan peningkatan mortalitas semakin tinggi pada waktu pemaparan 18 dan 24 jam. Sedangkan pada ketebalan 5 dan 2,5 cm, dari 4 waktu pemaparan yang diaplikasikan terdapat 3 waktu pemaparan yang menunjukkan mortalitas $\geq 50 \%$. Hasil analisis probit menunjukkan bahwa nilai $\mathrm{LD}_{50}$ dan $\mathrm{LD}_{95}$ semakin kecil dengan meningkatnya waktu pemaparan aplikasi (Tabel 2). Hal ini sesuai dengan terjadinya peningkatan mortalitas mulai dari waktu pemaparan 3 sampai dengan 9 jam.

\section{Hubungan dosis dan waktu pemaparan sulfuril fluorida}

Berdasarkan hasil analisis regresi dengan skala logaritmik, hubungan antara dosis dan waktu pemaparan untuk pengujian aplikasi pada ketebalan kayu sebesar 10,5, dan 2,5 cm diperoleh persamaan garis untuk 3 tingkat mortalitas $50 \%$, 90\%, dan 95\% (Tabel 3 dan Gambar 4). Hasil analisis regresi dengan skala logaritmik hubungan antara dosis dan waktu pemaparan untuk semua pengujian diperoleh nilai slope negatif, yaitu menunjukkan hubungan yang negatif, artinya makin lama waktu pemaparan maka makin rendah dosis yang diperlukan untuk menghasilkan masing-masing tingkat mortalitas 50\%, 90\%, dan 95\%. Regresi hubungan antara dosis dan waktu pemaparan pengujian aplikasi pada ketebalan kayu sebesar 5, dan 2,5 cm untuk semua tingkat mortalitas serta ketebalan kayu $10 \mathrm{~cm}$ dengan tingkat mortalitas $90 \%$ dan $95 \%$ diketahui nilai signifikasi $p>0,05$ maka hal ini berarti tidak terdapat pengaruh variabel bebas (waktu pemaparan) 
Tabel 2. Penduga parameter toksisitas sulfuril fluorida terhadap mortalitas kasta pekerja Cryptotermes cynocephalus dengan berbagai waktu pemaparan

\begin{tabular}{|c|c|c|c|c|c|}
\hline Ketebalan kayu & $\begin{array}{c}\text { Waktu } \\
\text { pemaparan } \\
\text { (jam) }\end{array}$ & $\mathrm{a} \pm \mathrm{GB}$ & $\mathrm{b} \pm \mathrm{GB}$ & $\begin{array}{c}\mathrm{LD}_{50} \\
(\mathrm{SK} 95 \%)\left(\mathrm{g} / \mathrm{m}^{3}\right)\end{array}$ & $\begin{array}{c}\mathrm{LD}_{95} \\
(\mathrm{SK} 95 \%)\left(\mathrm{g} / \mathrm{m}^{3}\right)\end{array}$ \\
\hline \multirow[t]{4}{*}{ Ketebalan $10 \mathrm{~cm}$} & 6 & $-8,610 \pm 2,053$ & $6,345 \pm 1,535$ & $\begin{array}{c}22,755 \\
(17,151-35,870)\end{array}$ & $\begin{array}{c}41,337 \\
(29,591-389,749)\end{array}$ \\
\hline & 12 & $-8,309 \pm 1,938$ & $6,579 \pm 1,509$ & $\begin{array}{c}18,318 \\
(12,476-24,986)\end{array}$ & $\begin{array}{c}32,575 \\
(24,224-151,009)\end{array}$ \\
\hline & 18 & $-6,474 \pm 1,122$ & $6,058 \pm 0,962$ & $\begin{array}{c}11,716 \\
(8,610-13,842)\end{array}$ & $\begin{array}{c}21,894 \\
(17,937-35,624)\end{array}$ \\
\hline & 24 & $-29,703 \pm 109777,2$ & $31,398 \pm 109777,2$ & $\begin{array}{c}8,831 \\
(-) \\
\end{array}$ & $\begin{array}{c}9,963 \\
(-) \\
\end{array}$ \\
\hline \multirow[t]{3}{*}{ Ketebalan $5 \mathrm{~cm}$} & 3 & $-2,944 \pm 0,521$ & $2,564 \pm 0,529$ & $\begin{array}{c}14,067 \\
(8,491-630,899)\end{array}$ & $\begin{array}{c}61,617 \\
(23,170-630,239)\end{array}$ \\
\hline & 6 & $-2,656 \pm 0,741$ & $3,418 \pm 0,866$ & $\begin{array}{c}5,983 \\
(-)\end{array}$ & $\begin{array}{c}18,121 \\
(-)\end{array}$ \\
\hline & 9 & $-0,165 \pm 0,334$ & $2,403 \pm 0,586$ & $\begin{array}{c}1,172 \\
(-)\end{array}$ & $\begin{array}{c}5,665 \\
(-)\end{array}$ \\
\hline \multirow[t]{3}{*}{ Ketebalan $2,5 \mathrm{~cm}$} & 3 & $-3,065 \pm 0,594$ & $3,918 \pm 0,688$ & $\begin{array}{c}6,055 \\
(2,607-10,975)\end{array}$ & $\begin{array}{c}15,920 \\
(9,392-274,050)\end{array}$ \\
\hline & 6 & $-2,514 \pm 0,770$ & $4,048 \pm 1,074$ & $\begin{array}{c}4,179 \\
(-)\end{array}$ & $\begin{array}{c}10,652 \\
(-)\end{array}$ \\
\hline & 9 & $0,331 \pm 0,317$ & $2,060 \pm 0,564$ & $\begin{array}{c}0,691 \\
(-)\end{array}$ & $\begin{array}{c}4,343 \\
(-)\end{array}$ \\
\hline
\end{tabular}

a: intersep garis regresi probit; b: kemiringan garis regresi probit; GB: galat baku; SK: selang kepercayaan.

Tabel 3. Persamaan garis hasil analisis regresi dengan skala logaritmik hubungan dosis dan waktu pemaparan sulfuril fluorida untuk 3 tingkat mortalitas

\begin{tabular}{lccc}
\hline $\begin{array}{l}\text { Dosis } \\
\text { mortalitas }\end{array}$ & $10 \mathrm{~cm}$ & $5 \mathrm{~cm}$ & $2,5 \mathrm{~cm}$ \\
\hline $\mathrm{LD}_{50}$ & $\log D=-0,683 \log t+1,925$ & $\log D=-2,151 \log t+2,249$ & $\log D=-1,821 \log t+1,755$ \\
& $\left(\mathrm{R}^{2}=0,920\right)(\mathrm{p}-$ value $=0,04)$ & $\left(\mathrm{R}^{2}=0,896\right)(\mathrm{p}$ - value $=0,21)$ & $\left(\mathrm{R}^{2}=0,759\right)(\mathrm{p}$ - value $=0,33)$ \\
$\mathrm{LD}_{90}$ & $\log D=-0,877 \log t+2,306$ & $\log D=-2,134 \log t+2,705$ & $\log D=-1,273 \log t+1,774$ \\
& $\left(\mathrm{R}^{2}=0,834\right)(\mathrm{p}$ - value $=0,08)$ & $\left(\mathrm{R}^{2}=0,968\right)(\mathrm{p}$ - value $=0,11)$ & $\left(\mathrm{R}^{2}=0,837\right)(\mathrm{p}$ - value $=0,26)$ \\
$\mathrm{LD}_{95}$ & $\log D=-0,933 \log t+2,415$ & $\log D=-2,129 \log t+2,834$ & $\log D=-1,118 \log t+1,779$ \\
& $\left(\mathrm{R}^{2}=0,808\right)(\mathrm{p}$ - value $=0,10)$ & $\left(\mathrm{R}^{2}=0,982\right) \mathrm{p}$ - value $\left.=0,09\right)$ & $\left(\mathrm{R}^{2}=0,871\right)(\mathrm{p}$ - value $=0,23)$ \\
\hline
\end{tabular}

terhadap variabel terikat (dosis), sedangkan untuk ketebalan kayu $10 \mathrm{~cm}$ dengan tingkat mortalitas $50 \%$ nilai signifikasi $\mathrm{p}<0,05$ maka hal ini berarti terdapat pengaruh variabel bebas (waktu pemaparan) terhadap variabel terikat (dosis).

\section{PEMBAHASAN}

Aplikasi sulfuril fluorida pada ketebalan $10 \mathrm{~cm}$ terhadap rayap $C$. cynocephalus dengan 4 waktu pemaparan $(6,12,18,24$ jam $)$ dengan 5 dosis $\left(10,15,20,25,30 \mathrm{~g} / \mathrm{m}^{3}\right)$ dan kontrol, terlihat bahwa peningkatan dosis sulfuril fluorida akan meningkatkan mortalitas rayap. Demikian juga halnya pada aplikasi sulfuril fluorida pada ketebalan 5 dan 2,5 cm dengan 4 waktu pemaparan $\left(1,3,6,9\right.$ jam) dengan 4 dosis $\left(2,5,10,15 \mathrm{~g} / \mathrm{m}^{3}\right)$ dan kontrol, terjadi peningkatan mortalitas rayap dengan semakin tingginya dosis dan waktu pemaparan dengan pola peningkatan mortalitas tertinggi dengan waktu pemaparan 6 jam. Penelitian yang dilakukan Su \& Scheffrahn (1986) menggunakan C. cavifrons yang diletakkan dalam kotak kayu dengan ketebalan 3,8 cm menunjukkan penggunaan dosis $3 \mathrm{mg} / \mathrm{liter}$ pada 10 jam 

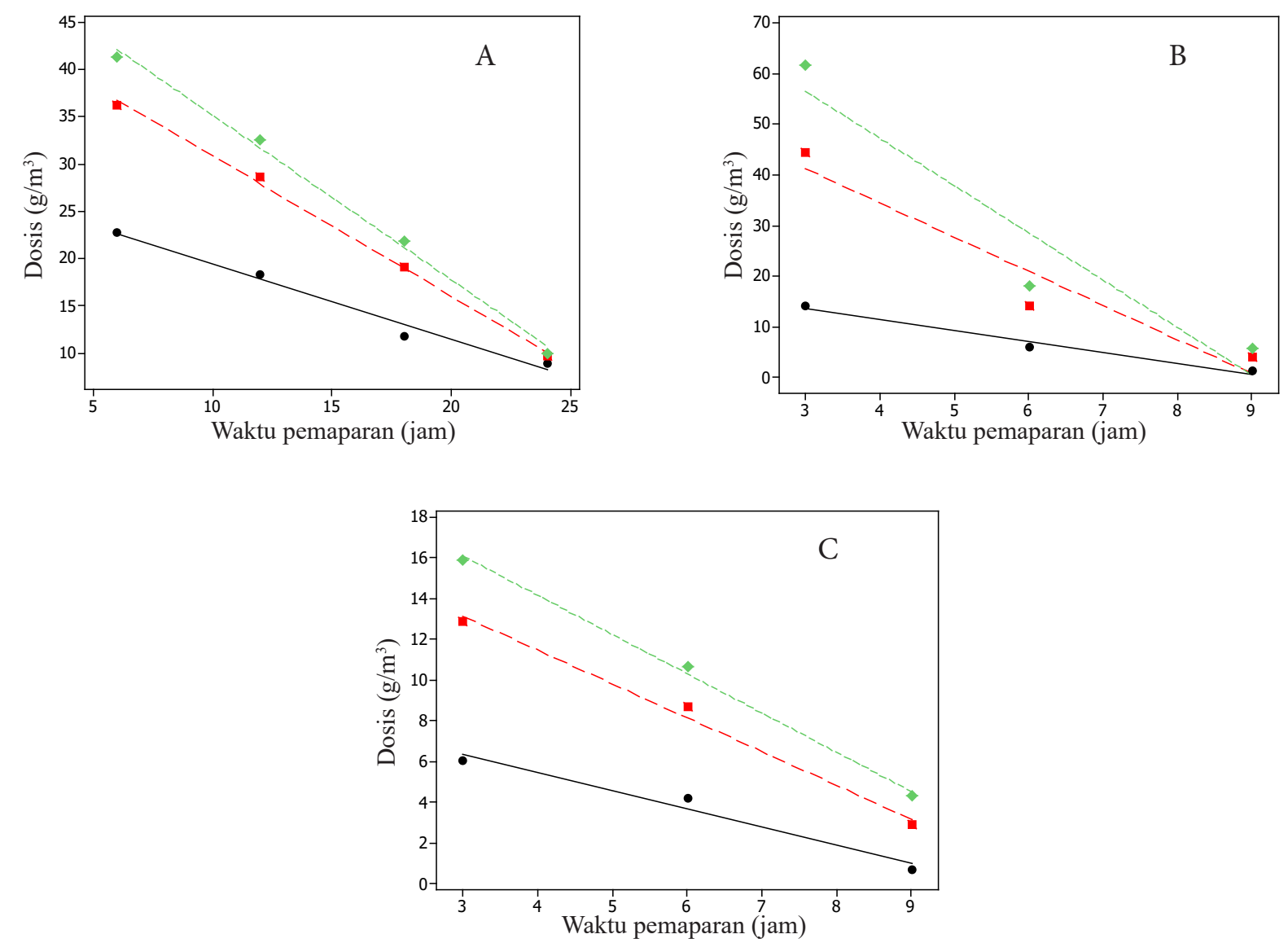

Gambar 4. Hubungan dosis-waktu aplikasi sulfuril fluorida terhadap Cryptotermes cynocephalus kasta pekerja pada tingkat kematian $50 \%, 90 \%$, dan $95 \%$ untuk pengujian pada ketebalan A: $10 \mathrm{~cm}$; B: $5 \mathrm{~cm} ; \mathrm{C}: 2,5 \mathrm{~cm} . \rightarrow: \mathrm{LD}_{50} ; \rightarrow: \mathrm{LD}_{90} ;-\mathrm{LD}_{95}$.

pemaparan, $6 \mathrm{mg} /$ liter pada 8 jam pemaparan, dan $12 \mathrm{mg} /$ liter pada 6 jam pemaparan memberikan mortalitas $100 \%$.

Mortalitas rayap C. cynocephalus pada rentang dosis dan waktu pemaparan aplikasi sulfuril fluorida yang diaplikasikan pada balok kayu menunjukkan bahwa fumigan sulfuril fluorida mampu masuk ke dalam kayu melalui pori-pori yang terdapat di dalam kayu. Semakin tebal balok kayu yang digunakan dalam aplikasi sulfuril fluorida maka semakin besar dosis dan lama waktu pemaparan yang dibutuhkan untuk aplikasi sulfuril fluorida.

Aktivitas sulfuril fluorida bergantung pada konsentrasi mencapai target hama dan lamanya pemaparan (Krieger 2001). Sulfuril fluorida memiliki cara kerja yang kompleks, masuk ke dalam tubuh serangga melalui spirakel (Dow Agrosciences 2002). Ion fluorida yang terkandung dalam fumigan sulfuril fluorida merupakan racun utama yang mengganggu metabolisme serangga (Dow Agrosciences 1999). Ion fluorida mencegah metabolisme lemak dengan mengganggu siklus glikolisis pada serangga yang dibutuhkan untuk mempertahankan kecukupan energi dalam bertahan hidup (Meikle et al. 1963). Ion fluorida dapat menghambat serapan oksigen, mengganggu keseimbangan normal fosfat, dan menghambat hidrolisis (pemecahan) asam lemak. Ion fluorida dalam sulfuril fluorida diperkirakan mengikat kalsium, kalium, dan magnesium. Enzim yang memerlukan ion magnesium untuk fungsi normal dihambat oleh sulfuril fluorida (Caroline 1997).

Secara umum, hubungan antara dosis dan waktu pemaparan adalah $\mathrm{C}^{\mathrm{n}} \mathrm{t}=\mathrm{k}$ (Winks 1984), di mana $\mathrm{C}=$ konsentrasi; $\mathrm{t}=$ waktu; $\mathrm{n}=$ indeks toksisitas; $\mathrm{k}=$ dosis untuk tingkat kematian spesifik. Pada ketebalan $10 \mathrm{~cm}$, diperoleh hubungan antara dosis dan waktu dari model $\mathrm{C}^{\mathrm{n}} \mathrm{t}=\mathrm{k}$ sebagai berikut: $\mathrm{LD}_{50}: \mathrm{C}^{1,465} \mathrm{t}=661,94 ; \mathrm{LD}_{90}: \mathrm{C}^{1,140} \mathrm{t}=425,40 ;$ $\mathrm{LD}_{95}: \mathrm{C}^{1,072 \mathrm{t}}=388,11$. Sementara itu, pada ketebalan sebesar 5 dan 2,5 cm diperoleh hubungan antara dosis dan waktu secara berurutan sebagai berikut: $\mathrm{LD}_{50}: \mathrm{C}^{0,465} \mathrm{t}=11,10 ; \mathrm{LD}_{90}: \mathrm{C}^{0,469} \mathrm{t}=18,54$; 
$\mathrm{LD}_{95}: \mathrm{C}^{0,470} \mathrm{t}=21,47$ dan $\mathrm{LD}_{50}: \mathrm{C}^{0,549} \mathrm{t}=9,21 ; \mathrm{LD}_{90}$ : $\mathrm{C}^{0,786 \mathrm{t}}=24,73 ; \mathrm{LD}_{95}: \mathrm{C}^{0,895} \mathrm{t}=39,06$.

Nilai indeks toksisitas pada ketebalan sebesar $10 \mathrm{~cm}$ adalah $>1$ maka model tersebut menunjukkan bahwa variabel dosis fumigan merupakan variabel dominan daripada variabel waktu pemaparan terhadap rayap kayu kering. Sementara itu, pada pada ketebalan sebesar 5 dan $2,5 \mathrm{~cm}$ diperoleh nilai indeks toksisitas $<1$ maka model tersebut menunjukkan bahwa variabel waktu pemaparan merupakan variabel dominan daripada variabel dosis fumigan. Penelitian yang dilakukan oleh $\mathrm{Su}$ et al. (1989) menggunakan rayap $C$. formosanus yang dipaparkan langsung dengan fumigan sulfuril fluorida dengan cara diletakkan di cawan petri menunjukkan bahwa $\mathrm{C}^{0,93} \mathrm{t}=\mathrm{k}$ merupakan model yang menggambarkan hubungan terhadap efikasi fumigan sulfuril fluorida untuk pengendalian rayap C. formosanus. Nilai indeks toksisitas pada ketebalan sebesar $10 \mathrm{~cm}$ berbeda dengan 5 dan 2,5 cm karena dosis fumigan dan waktu pemaparan aplikasi berbeda. Untuk pengujian aplikasi pada ketebalan 5 dan 2,5 cm dosis fumigan sulfuril fluorida yang digunakan rendah. Menurut $\mathrm{Su} \&$ Scheffrahn (1986), penyimpangan dari model sederhana $\mathrm{C}^{\mathrm{n}}$ $\mathrm{t}=\mathrm{k}$ terjadi ketika sulfuril fluorida menembus hambatan kayu yang basah untuk mencapai $C$. formosanus yang dihasilkan pada konsentrasi rendah. Hal ini disebabkan kelarutan fumigan sulfuril fluorida dalam air $\left(20{ }^{\circ} \mathrm{C}\right)$ yang rendah, yaitu 1040 mg/l (Leis 2007).

\section{KESIMPULAN}

Pada ketebalan kayu balok $10 \mathrm{~cm}$, pengendalian rayap kayu kering menggunakan fumigasi surfuril flourida efektif dilakukan pada dosis $30 \mathrm{~g} / \mathrm{m}^{3}$ dengan lama waktu pemaparan 18 jam atau pada dosis $15 \mathrm{~g} / \mathrm{m}^{3}$ dengan pemaparan $24 \mathrm{jam}$. Sementara itu, pada ketebalan $5 \mathrm{~cm}$ fumigasi sulfuril flourida efektif dilakukan pada dosis $10 \mathrm{~g} / \mathrm{m}^{3}$ dengan lama waktu pemaparan 9 jam; dan pada ketebalan kayu $2,5 \mathrm{~cm}$ pengendalian fumigasi surfuril flourida efektif dilakukan pada dosis $15 \mathrm{~g} / \mathrm{m}^{3}$ dengan waktu pemaparan 6 jam. Aplikasi sulfuril fluorida pada ketebalan $10 \mathrm{~cm}$ menunjukkan variabel dosis fumigan dominan daripada variabel waktu pemaparan, sedangkan pada ketebalan 5 dan $2,5 \mathrm{~cm}$ menunjukkan hasil yang sebaliknya.

\section{DAFTAR PUSTAKA}

Bess HA, Ota AK. 1960. Fumigation of building to control the dry-wood termite, Cryptotermes brevis. Journal of Economic Entomology 53:503510. doi: https://doi.org/10.1093/jee/53.4.503.

Caroline C. 1997. Fumigant factsheet: sulfuryl fluoride. Journal of Pesticide Reform 17:17-20.

Dow AgroSciences. 1999. General information on Vikane Gas Fumigant. Indianapolis (US): Dow AgroSciences LLC; Tersedia pada: http://www. pestgon.com/PDF/General\%20Information $\% 20$ on $\% 20$ Vikane.pdf. [diakses 2 Juni 2014].

Dow AgroSciences. 2002. Sulfuryl fluoride gas fumigant. Indianapolis (US): Dow AgroSciences LLC; Tersedia pada: http://www. cardinalproproducts.com/_literature_139048/ ProFume_Brochure. [diakses 24 Mei 2014].

Krieger RI, editor. 2001. Handbook of Pesticide Toxicology. $2^{\text {nd }}$ ed. Volume 2 Agents. California: Academic Press.

Leis L. 2007. Profume Gas Fumigant. Canberra: Australian Pesticides and Veterinary Medicines Authority.

Meikle RW, Stewart D, Globus OA. 1963. Drywood termite metabolism of vikane gas fumigant as shown by labeled pool technique. Journal of Agricultural and Food Chemistry 11:226-230. doi: https://doi.org/10.1021/jf60127a022.

Pearce MJ. 1997. Termites: Biology and pest management. Wallingford: CAB International.

[NPIC]. National Pesticide Information Center. 2000. Sulfuryl fluoride: general fact sheet. Oregon (US): Oregon State University. Tersedia pada: http://npic.orst.edu/factsheets/sftech.pdf. [diakses 7 Maret 2014].

Siregar AZ, Batubara R. 2007. Kerugian ekonomis akibat serangan rayap pada bangunan rumah masyarakat di dua kecamatan (Medan Denai dan Medan Labuhan). Jurnal Biologi Sumatera 2: 3-27.

Su NY, Scheffrahn RH. 1986. Field comparison of sulfuryl fluoride susceptibility among three termite species (Isoptera: Kalotermitidae, Rhinotermitidae). Journal of Economic Entomology 79:903-908. doi: https://doi.org/10.1093/ jee/79.4.903.

Su NY, Osbrink WLA, Scheffrahn RH. 1989. Concentration-time relationship for fumigant 
efficacy of sulfuryl fluoride against the formosan subterranean termite (Isoptera: Rhinotermitedae). Journal of Economic Entomology 82:156-158. doi: https://doi.org/10.1093/jee/82.1.156.

Sumargo W, Nanggara SG, Nainggolan FA, Apriani I. 2011. Potret Keadaan Hutan Indonesia Periode Tahun 2000-2009. Ed ke-1. Bogor: Forest Watch Indonesia.

Tho YP. 1992. Termite of Penninsular Malaysia. Kuala Lumpur: Forest Reserach Institute of Malaysia.
[UNEP] United Nations Environment Programme. 2014. Phasing-Out methyl bromide in developing countries. Nairobi: United Nations Enviroment Programme. Tersedia pada: http://www.unep. fr/ozonaction/information/mmcfiles/7674-ePhasing_out_methyl_bromide_in_developing countries.pdf. [diakses 11 November 2014].

Winks RG. 1984. The toxicity of phosphine to adults of Tribolium castaneum (Herbst): time as a dosage factor. Journal of Stored Products Research 20:45-56. doi: https://doi.org/10.1016/0022474X(84)90035-3. 